DEVELOPMENT OF MANAGEMENT

AND ENTREPRENEURSHIP METHODS

ON TRANSPORT, № 4 (77), 2021
РОЗВИТОК МЕТОДІВ

УПРАВЛІННЯ ТА ГОСПОДАРЮВАННЯ

НА ТРАНСПОРТІ, № 4 (77), 2021
УДК 629.047

JEL F01

DOI 10.31375/2226-1915-2021-4-99-109

\section{КОМЕРЦЙНІ РИЗИКИ \\ В СИСТЕМІ МОРСЬКИХ ПЕРЕВЕЗЕНЬ НА ПРИКЛАДІ КОНТЕЙНЕРОВОЗУ «EVER GIVEN»}

Ю.В. Загородня

к.е.н., доцент

Азовський морський інститут Наиіонального університету "Одеська морська академія»

\section{С.Б. Максимов} ст. викладач

Дунайський інститут

Національного університету

"Одеська морська академія»

Анотація. Стаття присвячена актуальному питанню комериійних ризиків у системі морських вантажних перевезень. Авторами проаналізовані питання безпеки судноплавства визначено, щуо сьогодні ие ключеве питання через велику кількість аварій та інцидентів на морі та їх негативний вплив на економічний і екологічний стан держави і світу в иілому. Авторами досліджені питання впливу внутрішніх та зовнішніх факторів на безпеку судноводіння. Визначено,що передбачення комериійних ризиків морських перевезень дозволить розробити механізми своєчасного подоланняі зможе знизити комериійні витрати усіх зацікавлених сторін морського перевезення вантажів. Розглянуті і проаналізовані основні причини загальної аварії контейнеровоза Ever Given у Суеиькому каналі і визначені наслідки, які вона спричинила для зацікавлених сторін перевезення та міжнародного морського судноплавства в иілому. Автори статті визначають комерційні ризики в результаті аварії Суецькому каналі. Визначена необхідність підвищення безпеки мореплавання $і$ постійного контролю за ї̈ забезпеченням, так яклюдський фактор є основною причиною аварійності суден. Дослідження доказали негативний вплив аварійних сітуацій на морі на змінення розмірів фрахтових ставок.

Ключові слова: Комериійна експлуатація суден, ризики, морський транспорт, морський порт, безпека судноводіння.

(С Загородня Ю.В., Максимов С.Б., 2021
УДК 629.047

JEL F01

DOI 10.31375/2226-1915-2021-4-99-109

\section{КОМЕРЧЕСКИЕ РИСКИ В СИСТЕМЕІ МОРСКИХ ПЕРЕВОЗОК НА ПРИМЕРЕ КОНТЕЙНЕРОВОЗА «EVER GIVEN»}

Ю.В. Загородня

к.э.н., доцент

Азовский морской институт Национального университета «Одеська морська академія»

\section{С.Б. Максимов}

ст. преподаватель

Дунайский институт

Национального университета

«Одесская морская академия»

Аннотация. Статья посвящена актуальному вопросу коммерческих рисков в системе морских грузовых перевозок. Авторами проанализированы вопросы безопасности судоходства и определено, что сегодня это ключевой вопрос из-за большого количества аварий и инцидентов на море и их негативное влияние на экономическое и экологическое состояние страны и мира в целом. Авторами исследованы вопросы влияния внутренних и внешних факторов на безопасность судовождения. Определено, что предвидение коммерческих рисков морских перевозок позволит разработать механизмы своевременного преодоления и сможет снизить коммерческие расходы всех заинтересованных сторон морской перевозки груза. Рассмотрены и проанализированы основные причины общей аварии контейнеровоза Ever Given в Суэцком канале $u$ определень последствия, которые она причинила для заинтересованных сторон перевозки и международного морского судоходства в иелом. Авторы статьи определяют коммерческие риски в результате аварии в Суэиком канале. Определена необходимость повышения безопасности мореплавания и постоянного контроля над ее обеспечением, так как человеческий фактор является основной причиной аварийности судов. Исследования доказали негативное влияние аварийных ситуаций на море на изменение размера фрахтовых ставок.

Ключевые слова: коммерческая эксплуатаџия судна, риски, морской транспорт, морской порт, безопасность судовождения. 
UDC 629.047

JEL F01

DOI 10.31375/2226-1915-2021-4-99-109

\title{
COMMERCIAL RISKS IN THE SEA TRANSPORTATION SYSTEM ON THE EXAMPLE OF THE «EVER GIVEN» CONTAINER CARRIER
}

\author{
Yuliia Zahorodnia \\ $\mathrm{PhD}$ (Economics), Associate Professor \\ Azov Maritime Institute of the National University «Odessa Maritime academy» \\ Sergiy Maksymov \\ Senior Lecturer of the Engineering Department \\ Danube Institute of the National University «Odesa Maritime Academy», Odessa, Ukraine
}

Abstract. Every year there is an intensive increase in tonnage and operational speed of vessels in the competition to improve the quality of transport and logistics services. Ship management needs to work in difficult, sometimes extreme conditions. It is necessary to comply with the commercial conditions of charters and not to violate the terms of delivery, to ensure the proper quality of cargo on board the vessel, as well as to comply with the conditions of safety of navigation in difficult weather conditions. All this affects the quality of cargo transportation.

Purpose. The purpose of this article is to systematize various aspects of the commercial operation of a vessel, identify possible commercial risks of sea transportation, as well as factors influencing them.

Methods. To solve the problem, the following methods were used: the method of theoretical generalization, the method of analysis and synthesis, the method of systematization, the method of deduction.

Results. It has been determined that the anticipation of commercial risks of sea transportation will allow to develop mechanisms for their timely overcoming and reduce the commercial costs of all interested parties in the carriage of goods by sea. The main reasons for the general accident of the container ship Ever Given in the Suez Canal are considered and analyzed and the consequences that it caused for the stakeholders of transportation and international maritime shipping in general are identified.

Originality. Potential commercial risks of sea transportation have been identified using the example of the accident with the container ship «Ever Given». It is proposed to develop alternative options for a prompt solution to such problems in the future.

Output. The blockage of the Suez Canal by the container ship Ever Given will have longterm repercussions, but such incidents could be deliberately provoked, affecting global and local trade in a targeted manner. There is a need to improve the safety of navigation by optimizing pilotage, especially during sandstorms and other situations where visibility is difficult. safety.

Keywords: commercial operation of a vessel, risks, sea transport, seaport, navigation

Постановка проблеми. Обсяг міжнародної торгівлі невпинно збільшується 3 кожним роком. Разом 3 ростом обсягів торгівлі зростає частка морських перевезень, це призводить до постійної інтенсифікації активності людини в морі. Наукові досягнення в частині технічної експлуатації сучасних суден, націлені на зниження аварійності та підвищення 
DEVELOPMENT OF MANAGEMENT

AND ENTREPRENEURSHIP METHODS ON TRANSPORT, № 4 (77), 2021
РОЗВИТОК МЕТОДІВ

УПРАВЛІННЯ ТА ГОСПОДАРЮВАННЯ

НА ТРАНСПОРТІ, № 4 (77), 2021 комерційної ефективності експлуатації флоту. Однак, питання безпеки та безаварійності в роботі судноплавства $\epsilon$ ключовим і сьогодні, так як число аварій на морі практично не скорочується, щорічно забираючи людські життя, завдаючи відчутної шкоди світовій економіці і шкоди навколишньому середовищу. Передбачення комерційних ризиків морських перевезень дозволить розробити механізми ïx своєчасного подолання та зможе знизити комерційні витрати зацікавлених сторін.

Аналіз останніх досліджень і публікацій. Аналізуючи джерела вітчизняних $[1 ; 3 ; 10]$ і зарубіжних вчених $[2 ; 5 ; 6 ; 11 ; 12]$, фахівців морської галузі в питаннях комерційних ризиків [4; 7-9; 13-15] та їх впливу на ефективність діяльності судноплавних компаній авторами відзначено, що ця проблема недостатньо досліджена та потребує доопрацювання в повній мірі для підвищення безпеки судноплавства та зменшення комерційних витрат всіх учасників морських перевезень вантажів.

Мета статті - аналіз комерційних ризиків морських перевезень, виявлення шляхів їх мінімізації для підвищення комерційної вигоди рейсу та можливостей спрогнозувати всі види ризиків на прикладі контейнеровозу Ever Given.

Виклад основного матеріалу дослідження. Щорічно відбувається інтенсивне збільшення тоннажу i експлуатаційної швидкості суден в конкурентній боротьбі за поліпшення якості транспортно-логістичних послуг. Менеджменту суден необхідно працювати в складних, часом екстремальних, умовах, дотримуючись ко- мерційних умов чартерів (договорів морських перевезень), не порушуючи термінів доставки і забезпечуючи належну якість вантажу на борту судна, водночас дотримуючись умов забезпечення безпеки судноводіння в складних метеорологічних умовах, а також перебуваючи в небезпечних районах плавання. Все це позначається на якості перевезення вантажу. Втома, постійний стрес, складні умови депривації, тривалі контракти без можливості своєчасного списання та інші зовнішні та внутрішні фактори призводять до неуважності, втрати контролю i, як наслідок, до аварійних ситуацій, що, в свою чергу, позначається на ефективності комерційної роботи судна.

До комерційних ризиків морських перевезень вантажу можна віднести наступні [1]:

- вплив нездоланної сили природи: цунамі, шторм тощо;

- випадковості, яких можна уникнути, але неможливо передбачити: посадка судна на мілину (винятком є навмисна посадка судна на мілину 3 метою запобігання більших комерційних витрат);

- військові дії, громадянські війни, страйки, саботажі тощо;

- людський фактор, до якого відносяться, наприклад, навігаційні помилки в судноводінні екіпажу та лоцмана;

- ризики комерційних помилок: під час прийому та відвантаження вантажу, розміщення, зберігання;

- вантажні ризики: втрата, нестача, затримка подачі під завантаження;

- захоплення піратами тощо. 
DEVELOPMENT OF MANAGEMENT

AND ENTREPRENEURSHIP METHODS ON TRANSPORT, № 4 (77), 2021
РОЗВИТОК МЕТОДІВ

УПРАВЛІННЯ ТА ГОСПОДАРЮВАННЯ

НА ТРАНСПОРТІ, № 4 (77), 2021
Аварія контейнеровозу «Ever Given» (2018 рік, прапор Панама, технічний нагляд - Американський Реєстр, відповідальність застрахована у Клубі взаємного страхування UK P\&I. Попередній Port State Control проведено 27 лютого у Великій Британії, було виявлено 3 недоліки) компанії Evergreen Marine в Суецькому каналі 23 березня 2021 року показала неможливість передбачення всіх комерційних ризиків, а також виявила вразливість міжнародної морської торгівлі від зовнішніх факторів [2]. Сьогодні Суецький канал є воротами для руху товарів між Свропою i Азією. Всього з 2010 по кінець 2019 року було зареєстровано 75 інцидентів в каналі. Більше третини інцидентів були пов'язані 3 контейнеровозами. У сукупності інциденти, пов'язані з посадкою на мілину, зіткненнями, складають половину всіх інцидентів із судноплавством у Суецькому каналі за останнє десятиріччя.

У 2019 році Суецький канал відповідав за транзит більше 19000 суден, що становить майже 1,25 млрд. тонн вантажів. Вважається, що це становить близько $13 \%$ світової торгівлі, тому будь-яке блокування має значні економічні наслідки для всіх зацікавлених сторін перевезення [3]. Ширина Суецького каналу складає 350 метрів. Як показав досвід, в сучасних умовах збільшення лінійних характеристик суден, цієї ширини стає замало для безпечного проходження судном каналу. Контейнеровоз «Ever Given» має длину 400 м, 59 метрів в найширшому місці і 16 метрів в глибину нижче ватерлінії. Це робить йо- го одним 3 найбільших контейнеровозів в світі, здатним перевозити більше 18000 контейнерів. Залежно від серйозності посадки на мілину, порятунок і повторне плавання цього типу судна - складна операція, яка вимагає спеціального обладнання i потенційно багато часу для iіi здійснення. Розвернувшись поперек каналу судно повністю перекрило рух іншим суднам в обидві сторони (рис.1).

Лише через 6 днів, а саме 29 березня операції по зняттю $з$ мілини були завершені. Судно було відбуксоване до озеру Great Bitter Lake [5]. Якби інцидент стався всього в декількох кілометрах вниз по напрямку до морського порту Суец, де закінчується канал, судно сіло б на мілину на берегах, що складаються 3 каменів, а не піску. Удар міг завдати серйозної шкоди корпусу, що ускладнило рятувальні операції та суттєво збільшили б комерційні витрати всіх постраждалих сторін.

Вже 1 квітня 2021 року судновласник «Ever Given» зробив заяву про загальну аварію (General Average) [6], головними ознаками якої $\epsilon$ наявність загальної небезпеки для судна, вантажу та фрахту; навмисність дій; надзвичайність і розумність. Це означає, що покриття всіх витрат розподіляється між всіма зацікавленими сторонами перевезення. 7 липня 2021 року контейнеровоз «Ever Given» залишив Суецький канал. Стоянка під арештом склала майже 100 діб без двох днів, що спричинило до ще більших втрат 3 боку судновласника. 


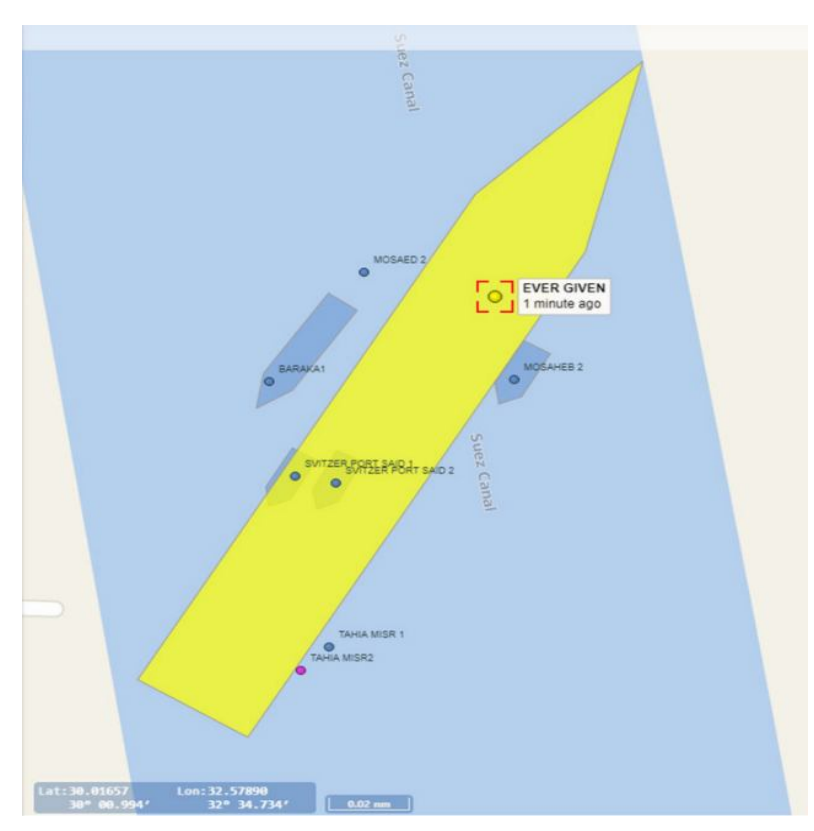

Рис. 1. Положення контейнеровозу Ever Given в Суецькому каналі

Джерело: розроблено авторами на основі [4]

Судна стають все більше, їх залежність від вузьких судноплавних маршрутів, побудованих в більш ранню епоху, виглядає все більш ризикованою. Якщо в 1968 році максимальна кількість перевезених контейнерів складала $1530 \mathrm{TEU}$, то в 2020 році цей показник виріс до $24000 \mathrm{TEU}$ (рис. 2).

На сьогоднішній день не має офіційної версії стосовно причини посадки контейнеровозу на мілину, icнують тільки припущення, а саме:

- сильний вітер, який розвернув судно;

- технічні несправності;

- перевищення швидкості під час проходження каналом;

- помилкові дії лоцманів;

- відсутність буксирного супроводу.
Сильні вітри, на думку деяких спеціалістів, стали причиною заблокування контейнеровозом вузької протоки, яка служить торговою артерією, що з'єднує Середземне і Червоне моря. Але через те, що судноплавство так сильно залежить від таких вузьких каналів, ймовірність цих інцидентів існує постійно, а як наслідок, підвищується комерційний ризик морських перевезень.

Закриття Суецького каналу крайне негативно сказалося на глобальних ланцюгах поставок. Черга в обидві сторони каналу складала близько 350 суден. Через перспективу затримки нафтових танкерів в каналі суттєво піднялись ціни на нафту (більш ніж на $2 \%$ ) та фрахтові ставки на танкери [8]. 


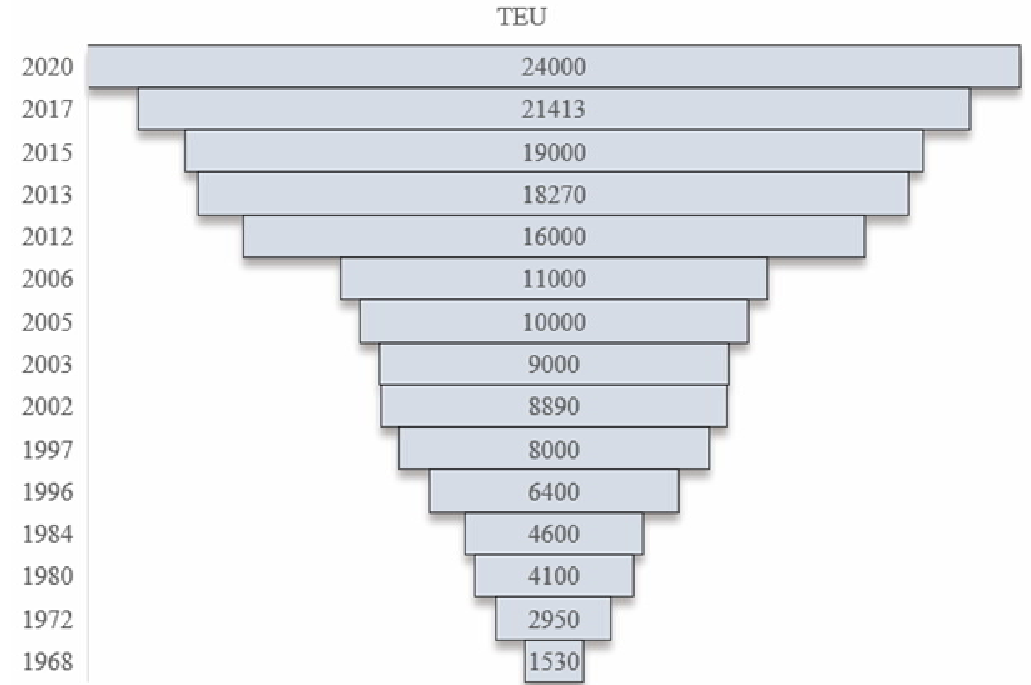

Рис. 2. Динаміка збільшення розмірів контейнеровозів y період 1968-2020 pp.

Джерело: розроблено авторами на основі [7]

Деякі перевізники прийняли рішення направити судна в обхід Африки для уникнення додаткових комерційних витрат під час очікування зняття судна 3 мілини та відновлення руху суден. Можливість обійти мис Доброї Надії завжди доступна, хоча це додає близько 5000 морських миль або 9000 кілометрів до типової подорожі з Близького Сходу в Європу. 3 Сінгапуру в Європу менше, приблизно от 3000 до 3500 морських миль. Це означає набагато більші витрати палива i набагато більший час в дорозі (приблизно на 10-15 днів більше, в залежності від швидкості судна). Таким чином, це значно дорожче, але судно може заощадити на зборах за Суецький канал. Ще одне міркування - погода, яка може погіршитися при обході мису. Таким чином, це не кращий вибір для невеликих суден, у яких може не вистачити палива. Багато що також залежить від ціни на паливо і переважаючих ставок фрахтування суден. Іноді більш високі ціни на паливо і чартерні ставки в поєднанні можуть зробити більш тривалу поїздку рентабельною. Через блокування на кілька днів суднам, ймовірно, не має сенсу міняти маршрут, тільки якщо передбачені більш тривалі затримки.

Можна виділити наступні комерційні ризики внаслідок аварії в Суецькому каналі:

1.Затримки в портах через їх перевантаженість.

2.3бій в ланцюгах поставок.

3.Розірвання чартерів.

4.Зростання морського фрахту.

5. Ризики пов'язані з забезпеченням схоронності вантажів. 
DEVELOPMENT OF MANAGEMENT

AND ENTREPRENEURSHIP METHODS ON TRANSPORT, № 4 (77), 2021
РОЗВИТОК МЕТОДІВ

УПРАВЛІННЯ ТА ГОСПОДАРЮВАННЯ

НА ТРАНСПОРТІ, № 4 (77), 2021
Від 10 до $12 \%$ світової торгівлі проходить через Суецький канал. Щодня по ньому проходить більше 50 суден. Lloyd's List підрахував, що через це блокування зупинило морський рух на суму близько 10 млрд. доларів, що негативно сказалося на глобальні лінії постачання [9]. Канал $\epsilon$ важливим маршрутом для транспортування нафти і скрапленого природного газу з Близького Сходу в Європу, а також існує ймовірність затримки поставок технологічним $\mathrm{i}$ автомобільним компаніям.

Страховики роками попереджали, що збільшення розмірів суден веде до більшого накопичення ризику. Ці побоювання зараз реалізуються, потенційно, компенсуючи довгострокові поліпшення в області безпеки та управління ризиками. Такі кораблі приносять судновласникам комерційну вигоду та економію за рахунок масштабу, але також непропорційно великі витрати, коли щось йде не так. Дії в разі інцидентів за участю великих суден, таких як пожежі, посадки на мілину і зіткнення, стають більш складними і дорогими.

Пожежі на борту великих контейнеровозів стали звичайним явищем, і такі інциденти легко можуть привести до великих претензій на сотні мільйонів доларів, а то й більше. Гіпотетичний сценарій збитків найгіршого випадку, пов'язаний з зіткненням і посадкою на мілину двох великих контейнеровозів або контейнеровоза і круїзного лайнера, може призвести до збитків в розмірі 4 мільярдів доларів, якщо будуть включені витрати на складний порятунок і видалення уламків, а також будь-які екологічні претензії.
Розмір судна може значно збільшити витрати на утилізацію i загальну аварію. Мега-судам потрібні спеціальні буксири, і знайти портпритулок, здатний прийняти таке велике судно, може бути складно, що збільшує витрати на рятувальні операціï.

Очевидно, що в деяких сегментах судноплавства заходи щодо запобігання втрат не встигають за масштабуванням суден. Це те, що необхідно вирішувати на етапі проектування. Сьогодні проектуються контейнеровози на $24000 \mathrm{TEU}$, отже подібні аварії та інциденти можуть відбуватися більш регулярно в майбутньому.

Крім того, великі розміри суден унеможливлюють їх захід судна в інші порти в зв'язку з обмеженою спроможністю прийняття суден таких розмірів. Недостатність глибин, довжини причалів, складських площ, розмірів перевантажувального обладнання ступень автоматизації та інші фактори $є$ основними з причин. Вирішення цих питань вимагає інвестицій в великих обсягах, що можливе лише в випадку впровадження нових логістичних схем зі сталим вантажообігом, а не разових заходів судна.

Незважаючи на те, що в логістиці ефект «пляшкового горличка» $\epsilon$ достатньо розповсюдженим явищем i 3 ним стикалися майже усі логістичні компанії - події в Суецькому каналі показали масштабність ризиків і неспроможність оперативного вирішення питання залучення альтернативних щляхів. Відсутність альтернативи південної частині каналу говорить про необхідність диференціації ланцюгів поставок, необхідність пошуку, розробки альтернативних шляхів 
DEVELOPMENT OF MANAGEMENT

AND ENTREPRENEURSHIP METHODS ON TRANSPORT, № 4 (77), 2021
РОЗВИТОК МЕТОДІВ

УПРАВЛІННЯ ТА ГОСПОДАРЮВАННЯ

НА ТРАНСПОРТІ, № 4 (77), 2021 задля нівелювання ризиків. Так, якщо раніше компанії формували ланцюги постачання по принципу «точно в строк» («just in time»), то тепер необхідно переходити к моделі «в випадку чого» («just in case»). Враховуючи достатньо широку номенклатуру вантажів і їх обсяги к кожній групі вантажів можуть бути розглянути власні альтернативні ланцюги поставок, більшість 3 яких не може розглядатись як повноцінна альтернатива, але в критичних випадках може виконувати роль резервної транспортної артерії. Це можуть бути:

- слідування в обхід мису Доброї Надії (здебільшого для великих партій масових, навалювальних, наливних вантажів);

- використання залізничного транспорту (генеральні, контейнерні вантажі); ний газ);

- трубопроводи (нафта, природ-

- інші.

Інцидент 3 контейнеровозом «Ever Given» призвів до накопичення в портах вантажів для відправлення, суден в очкуванні вивантаження та завантаження, через порушення нормального технологічного циклу знизився коефіцієнт вантажообігу, збільшився час обробки вантажу, знаходьження його на складських площах. Наприклад, прибуття великих обсягів навантажених контейнерів в поєднанні з внутрішніми правилами розподілу, призвело до зменшення пропускної спроможності, накопичення вантажів та дисбалансу контейнерного парку, оскільки непропорційна задіяність великої кількості навантажених погіршила доступність порожніх контейнерів для навантаження. Це призвело до виникнення додаткових небезпек, пов'язаних 3 подовженим терміном знаходження вантажів на складах. Небезпеки можна виділити в три основні групи:

- небезпеки пов'язані 3 недотриманням режимів зберігання;

- небезпеки пов'язані з проявою скритих властивостей вантажів, взаємний шкідливий вплив, порушення питань сумісності;

- зростання вірогідності крадіжок.

Відповідальність за затримки в більшості випадків залежить від формулювання умов в чартері та яке діє страхове покриття. Умовно їх можна поділити на дві групи: позиція таймчартеру та рейсового чартеру. Аналізуючи договірні наслідки проформ чартерів Балтийської міжнародної морської ради (ВIMCO), рекомендації BIMCO для судновласників та фрахтівників, можна дійти висновку, що, в цілому, договірні засади морського перевезення будуть змінюватися та доповняться 3 урахуванням нових факторів.

Наразі:

- згідно стандартному тайм-чартеру та рейсовому чартеру (BALTIME або ВОХТIME) судновласники можуть опинитися під загрозою анулювання чартеру $[14 ; 15]$. В обох формах чітко прописано, що в випадку затримки прибуття судна судновласник може опинитись під загрозою анулювання чартеру;

- в рамках стандартних чартерів NYPE, BALTIME Ta BOXTIME (тайм-чартер) не передбачувана можливість фрахтівника вивести судно із тайм-чартеру на період затримки судна викликаної обставинами пов'яза- 
ними 3 «Ever Given», затримка виникла не 3 вини судна або судновласника;

- при рейсовому чартері, якщо сторони уклали договір в рамках стандартного договору GENCON, витрати, що пов'язані з затримкою судна в рейсі будуть віднесені на рахунок судновласника;

- щодо строків поставки до судновласників також не можуть бути застосовані фінансові санкції, так як згідно з умовами рейсового чартеру на судновласнику лежить зобов’язання «розумного» відправлення вантажу в портах навантаження та вивантаження і затримка, що пов'язана 3 блокуванням Суецького каналу, не може бути підставою для застосування будь-яких санкцій.

Tому, в даному випадку, в зв'язку 3 неординарністю ситуації, BIMCO рекомендує судновласникам i фрахтувальникам приступити до діа- логу задля усунення фінансових наслідків інциденту.

Всі ці наведені фактори закономірно можна розглядати як передумови для зростання фрахту. По-перше, величина страхового покриття пропорційно залежна від рівня ризиків. По-друге, закладення в вартість перевезення можливих додаткових витрат, пов'язаних 3 зміненням ланцюгів постачання. Втретє, як наслідок, збільшення логістичних витрат.

Висновки та пропозиції. Таким чином, блокування Суецького каналу контейнеровозом «Ever Given» буде мати довгострокові наслідки, але подібні інциденти можуть бути спровоковані зловмисно, викликаючи цілеспрямовані або широкомасштабні дії на глобальну і місцеву торгівлю. Необхідно удосконалити систему безпеки судноплавства шляхом оптимізації лоцманської проводки, особливо під час піщаних бур та інших сценаpiїв, коли видимість ускладнена.

\section{СПИСОК ЛІТЕРАТУРИ}

1. Загородня Ю.В. Мінімізачія комериійних витрат морських перевезень шляхом підвищення безпеки мореплавства // Вісник Хмельницький, № 4. T. 2 (284). 2020. C. 97-100.

2. Иниидент с «Ever Given» глазами юриста // Seanews. URL: https:// seanews.ru/2021/03/26/ru-incident-s-ever-given-glazami-jurista/

3. Світова торгівля «застрягла» в Суецькому каналі // Укрінформ. URL: https://www.ukrinform.ua/rubric-economy/3216170-svitova-torgivla-zastraglav-sueckomu-kanali-vtrati-vze-230-milardiv.html

4. EVER GIVEN // VesselFinder. URL: https://www.vesselfinder.com/ru/ vessels/EVER-GIVEN-IMO-9811000

5. Ever Given: проблемы только начинаются // USM. URL:

6. Общая авария на судне EVER GIVEN // Panditrans. URL: https://www. panditrans.com/news/obshhaya-avariya-na-sudne-ever-given-pozitsiya-ttkluba-i-obshhie-rekomendatsii-ekspeditoram-i-gruzovladeltsam/ 
7. The Suez Canal blockage and mega ship risks // Allianz Global Corporate \& Specialty. URL: https://www.agcs.allianz.com/news-and-insights/expert-riskarticles/suez-canal-mega-ships.html

8. Suez Canal container ship accident is a worst - case scenario for global trade // The Conversation. URL: https://theconversation.com/suez-canalcontainer-ship-accident-is-a-worst-case-scenario-for-global-trade-157802

9. The Suez Canal blockage - potential implications for marine insurance claims // The Conversation. URL: https://www.agcs.allianz.com/news-andinsights/expert-risk-articles/suez-canal-marine-insurance-claims.html

10. Загородня Ю.В. Комериійні ризики морських перевезень в умовах льодової навігації // Розвиток методів управління та господарювання на трансnopmi, 1(74). Odeca: OHMУ, 2021. C. 5-13. DOI https:// doi.org/ 10.31375/2226-1915-2021-1-5-13

11. Reed Smith Client Alert Combined «Prevention of Shipment» clause replaces Prohibition, Force Majeure and Strikes clauses in standard grain trading contracts, 2014.

12. Willsher R. Shipment Risk. In: Export Finance. Finance and Capital Markets. Palgrave Macmillan, London, 1995.

13. A year of extremes in container shipping // BIMCO. URL: https://www. bimco.org/Events/20210914\%20SnP\%20Global\%20Platts

14. BALTIME 1939 (AS REVISED 2001) // BIMCO. URL: https://www. bimco.org/ contracts-and-clauses/bimco-contracts/baltime-1939-as-revised-2001\#

15. BOXTIME // BIMCO. URL: https://www.bimco.org/ Contracts\%20and \%20 clauses/BIMCO\%20Contracts/BOXTIME

\section{REFERENCES}

1. Zahorodnia, Yu.V. (2020). Minimizatsiia komertsiinykh vytrat morskykh perevezen shliakhom pidvyshchennia bezpeky moreplavstva [Minimize commercial shipping costs by improving maritime safety]. Visnyk Khmelnytskyi - Bulletin of Khmelnytsky. № 4, Tom 2 (284). C. 97-100. [in Ukrainian].

2. Intsident $s$ «Ever Given» glazami yurista. Retrieved from: https:// seanews.ru/2021/03/26/ru-incident-s-ever-given-glazami-jurista/ [in Russian]

3. Svitova torhivlia «zastriahla»v Suetskomu kanali [World trade is «stuck» in the Suez Canal]. Ukrinform. Retrieved from: https://www.ukrinform.ua/rubriceconomy/3216170-svitova-torgivla-zastragla-v-sueckomu-kanali-vtrati-vze230-milardiv.html [in Ukrainian].

4. EVER GIVEN // VesselFinder. Retrieved from: https://www.vesselfinder.com/ $\mathrm{ru} /$ vessels/EVER-GIVEN-IMO-9811000

5. Ever Given: problemyi tolko nachinayutsya // USM. Retrieved from: https://usm.media/ever-given-problemy-tolko-nachinayutsya/ [in Russian]

6. Obschaya avariya na sudne EVER GIVEN - rekomendatsii TT Kluba ekspeditoram i gruzovladeltsam [General average on board EVER GIVEN]. Panditrans. Retrieved from: https://www.panditrans.com/news/obshhaya- 
avariya-na-sudne-ever-given-pozitsiya-tt-kluba-i-obshhie-rekomendatsiiekspeditoram-i-gruzovladeltsam/ [in Russian]

7. The Suez Canal blockage and mega ship risks. Allianz Global Corporate \& Specialty. Retrieved from: https://www.agcs.allianz.com/news-and-insights/ expert-risk-articles/suez-canal-mega-ships.html

8. Suez Canal container ship accident is a worst-case scenario for global trade. The Conversation. Retrieved from: https://theconversation.com/suez-canalcontainer-ship-accident-is-a-worst-case-scenario-for-global-trade-157802

9. The Suez Canal blockage - potential implications for marine insurance claims. The Conversation. Retrieved from: https://www.agcs.allianz.com/news-andinsights/expert-risk-articles/suez-canal-marine-insurance-claims.html

10. Zahorodnia, Yu. V. (2021). Komertsiini ryzyky morskykh perevezen v umovakh lodovoi navihatsii [Commercial risks of sea transportation in the conditions of ice navigation]. Rozvytok metodiv upravlinnia ta hospodariuvannia na transporti - Development of management and entrepreneurship methods on transport, 1(74). Odesa: ONMU, 5-13. DOI: https://doi.org/10.31375/22261915-2021-1-5-13 [in Ukrainian].

11. Reed Smith (2014). Client Alert Combined «Prevention of Shipment» clause replaces Prohibition, Force Majeure and Strikes clauses in standard grain trading contracts.

12. Willsher, R. (1995). Shipment Risk. In: Export Finance. Finance and Capital Markets. Palgrave Macmillan, London.

13. A year of extremes in container shipping // BIMCO. Retrieved from: https:// www. bimco.org/Events/20210914\%20SnP\%20Global\%20Platts

14. BALTIME 1939 (AS REVISED 2001) // BIMCO. Retrieved from: https:// www.bimco.org/contracts-and-clauses/bimco-contracts/baltime-1939-asrevised-2001\#

15. BOXTIME // BIMCO. Retrieved from: https://www.bimco.org/Contracts\% 20and \%20clauses/BIMCO\%20Contracts/BOXTIME

Стаття надійшла до редакиії 06.12.2021

Посилання на статтю: Загородня Ю.В., Максимов С.Б. Комерційні ризики в системі морських перевезень на прикладі контейнеровозу «Ever Given» // Розвиток методів управління та господарювання на транспорті: Зб. наук. праць, 2021. № 4 (77). С. 99-109. DOI 10.31375/2226-1915-2021-4-99-109.

Article received 06.12.2021

Reference a JournalArtic Zahorodnia, Yuliia \& Maksymo, Sergiy. (2021). Commercial risks in the sea transportation system on the example of the «Ever Given» container carrier // Development of management and entrepreneurship methods on transport. 4 (77), 99-109. DOI 10.31375/2226-1915-2021-4-99-109. 